\title{
RESOLUTION OF THE SENATE \\ OF THE REPUBLIC OF POLAND \\ of 28 September 2018 \\ on the 40th anniversary of Cardinal \\ Karol Wojtyła's election as Pope John Paul II
}

W dniu 16 października 2018 r. przypada 40. rocznica wyboru Kardynała Karola Wojtyły - Jana Pawła II na Stolicę Piotrową. Senat Rzeczypospolitej Polskiej pragnie uczcić pierwszego Polaka na urzędzie św. Piotra, Głowę Kościoła Powszechnego, a zarazem syna naszej Ojczyzny, który na Polskę i jej dzieje patrzył oczyma wielkich romantyków. „Los ojczyzny waży się w sercu każdego Polaka”; „taka będzie Polska, jacy będą jej synowie i córki”- to myśli wyjęte z papieskiego nauczania.

Nikt tak jak On nie potrafił obudzić nadziei w sercach Polaków, których miliony uczestniczyło w spotkaniach na Jego pielgrzymich szlakach w Ojczyźnie, w Rzymie i na świecie. Cieszył się szacunkiem także tych, którzy nie zgadzali się z Jego wizją świata i człowieka. Był orędownikiem ekumenizmu i dialogu międzyreligijnego.

Określano Go przydomkiem - „Wielki”, między innymi ze względu na rekordy: odbył 104 pielgrzymki zagraniczne, w czasie których trzykrotnie pokonał odległość między Ziemią a Księżycem, co odpowiada 30 okrążeniom kuli ziemskiej; podróżując, spędził ponad 900 dni, tzn. ponad 2,5 roku, poza Watykanem, co stanowi około 11,5\% czasu trwania pontyfikatu; odwiedził ponad 140 państw, w tym wiele $\mathrm{z}$ nich kilkakrotnie. Nie obawiał się pojechać do Sarajewa, Libanu, Kijowa, Hawany, Aten czy Jerozolimy. Marzył o pielgrzymce do Rosji oraz Chin. Trudno wyobrazić sobie naszą epokę bez Jana Pawła II, nie sposób bowiem zliczyć wszystkich, którym w latach swego pontyfikatu dopomógł, z którymi się modlił i którzy szczęśliwie mogli zobaczyć Go z bliska.

Historycy czy socjologowie słusznie twierdzą, że Jego posługą i nauczaniem można by obdzielić kilku lub nawet kilkunastu papieży. Ogłosił bowiem 14 encyklik, 14 adhortacji apostolskich, 10 konstytucji, 37 listów apostolskich i 23 motu 
proprio, w których uporządkował naukę Kościoła, wydał Katechizm Kościoła Katolickiego, wygłosił tysiące przemówień.

Za jeden $\mathrm{z}$ istotnych elementów swojej posługi Jan Paweł II uważał wskazywanie wiernym wzorów świętości: przewodnicząc ponad 150 uroczystościom kanonizacyjnym i beatyfikacyjnym, ogłosił blisko 1300 błogosławionych, a 455 wyniósł do chwały świętości. Jeśli do tego dodamy różne inne rekordy tego pontyfikatu, synody biskupów, konsystorze kardynalskie, oficjalne wizyty głów państwa, audiencje generalne, w których uczestniczyło kilkadziesiąt milionów wiernych z wszystkich krajów świata, to nikt nie powinien mieć wątpliwości, że od 16 października 1978 r. do 2 kwietnia 2005 r. uczestniczyliśmy w wielkim i nadzwyczajnym wydarzeniu w Kościele, któremu na imię Jan Paweł II.

Wielkość tego pontyfikatu to bezapelacyjny wpływ na wydarzenia końca XX wieku. Papież z Polski przyczynił się do przemian w świecie, które doprowadziły do upadku imperium zła - jak prezydent USA Ronald Reagan nazwał Związek Radziecki. Osoba Jana Pawła II zostanie na zawsze związana z powstaniem ruchu „Solidarnośćc w Polsce, a w konsekwencji z upadkiem Muru Berlińskiego, z rozpadem żelaznej kurtyny, z wolnością krajów Europy Środkowo-Wschodniej.

Jan Paweł II przeszedł do historii jako Papież Kultu Miłosierdzia Bożego i Rodziny, obrońca małżeństwa i prawa do życia nienarodzonych, świętości życia od poczęcia do naturalnej śmierci. W jednej z wypowiedzi na ten temat Ojciec Święty stwierdził, że pragnie, aby to był Jego testament, sens pontyfikatu. Nauczał, że prawo dziecka do życia w rodzinie jest fundamentem cywilizacji i kultury. Jeśli nie ma poszanowania dla życia i rodziny, nie istnieją inne prawa, jak wolność, sprawiedliwość, godność człowieka.

Na pytanie, skąd Jan Paweł II czerpał tyle nadziei, aby z takim przekonaniem głosić prawdy i wartości kwestionowane nierzadko przez świat, skąd płynęła Jego pewność, że dobro i miłość, sprawiedliwość i pokój, wolność i prawda mogą stać się na powrót wartościami dla ludzkich sumień, stanowić fundament każdej odpowiedzialnej etyki, należy odpowiedzieć: On na serio, osobiście, przyjął do serca zawołanie swego pontyfikatu i żył według niego - „aby nie lękać się Chrystusa, nie lękać się otworzyć drzwi Chrystusowi”.

Uchwała podlega ogłoszeniu w Dzienniku Urzędowym Rzeczypospolitej Polskiej „Monitor Polski”.
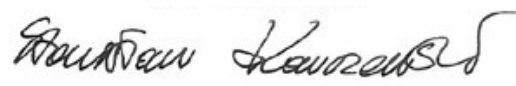

Stanisław Karczewski Marszałek Senatu 


\section{RESOLUTION OF THE SENATE \\ OF THE REPUBLIC OF POLAND \\ of 28 September 2018 \\ on the 40th anniversary of Cardinal \\ Karol Wojtyła's election as Pope John Paul II}

The 16th of October 2018 marks the 40th anniversary of Cardinal Karol Wojtyła's election as Pope John Paul II. The Senate of the Republic of Poland wishes to honour the first Pole to be elected to St Peter's throne, the Head of the universal Church and a son of our Homeland, who looked upon Poland and its history through the eyes of the great Romantics. "The destiny of our homeland is decided in the heart of every Pole"; "such will be Poland as are its sons and daughters", these are some of the Pope's teachings.

He had no equal in instilling hope in the hearts of Poles, millions of whom participated in the meetings He held on His pilgrimage trails in His Homeland, in Rome and around the world. He also commanded respect of those who did not share His vision of the world and of man. He was an advocate of ecumenism and interreligious dialogue.

He was referred to with the epithet "the Great", partially because of His record achievements: He made 104 foreign pilgrimages with the mileage encompassing three times the distance between the Earth and the Moon, i.e. 30 laps around the Earth; during His travels He spent 900 days or over 2.5 years outside the Vatican, i.e. approximately $11.5 \%$ of His pontificate; He also visited more than 140 countries, many of them several times. He was not afraid of going to Sarajevo, Lebanon, Kyiv, Havana, Athens or Jerusalem. His dream was to make a pilgrimage to Russia and China. It would be difficult to imagine our era without John Paul II as beyond any count are all those He helped during His pontificate, with whom He prayed and who lived to see Him up close.

Historians and sociologists are right to say that His service and teaching could be shared among many other popes. With a view to re-organising the Church's teaching He promulgated 14 encyclicals, 14 apostolic exhortations, 10 apostolic constitutions, 37 apostolic letters and 23 motu proprios, published the Catechism of the Catholic Church and delivered thousands of speeches. 
John Paul II believed that one of the key elements of His service consisted in showing the faithful the paragons of sainthood: He officiated at over 150 canonisation and beatification ceremonies, beatifying over 1,300 people and canonising 455 saints. If considered together with some other records of this pontificate, such as synods of bishops, consistories of cardinals, official visits by heads of state and general audiences with dozens of millions of the participating faithful from all countries of the world, then no one should have reason to doubt that from 16 October 1978 to 2 April 2005 we were part of a great and extraordinary event within the Church called John Paul II.

His great pontificate had an indisputable impact on the events which took place at the end of the 2oth century. The Polish Pope contributed to the world's developments which led to the collapse of the evil empire - the phrase used by U.S. President Ronald Reagan to refer to the Soviet Union. The figure of John Paul II will always be associated with the emergence of the "Solidarity" Movement in Poland and, as a result, with the fall of the Berlin Wall, the collapse of the Iron Curtain and the freedom of the Central and Eastern European countries.

John Paul II left His landmarks in history as a Pope of the Divine Mercy and the Family, a defender of marriage, the right of the unborn to live and the holiness of life from the moment of conception until natural death. In this respect, the Holy Father once stated that He wished it to be his testament, the sense of His pontificate. He taught that a child's right to live in a family was the foundation of civilisation and culture. Where there is no respect for life and family, there can be no other rights, such as freedom, justice and human dignity.

If one were to ask why John Paul II had so much hope that He was able to put so much conviction and effort in spreading the truths and values which were often contested by the world, why He was so certain that the values such as good and love, justice and peace, freedom and truth could be re-instilled into people's consciences as the foundation of responsible ethics, the answer is the following: He seriously and personally took to heart the motto of His pontificate and lived up to it: "Do not be afraid. Open wide the doors for Christ".

This resolution will be published in the Official Journal of the Republic of Poland "Monitor Polski". 